\title{
Fatty acid composition and dietary fibre constituents of mushrooms of North India
}

\author{
Rajni Goyal ${ }^{1 *}$, Raj Bala Grewal' ${ }^{2}$ Ramesh Kumar Goyal ${ }^{3}$ \\ ${ }^{1}$ Department of Home Science, University College, Kurukshetra University, Kurukshetra, India; ${ }^{2}$ Center of Food Sciene \&Technology, CCS \\ Haryana Agricultural University, Hisar, India; ${ }^{3}$ Department of Horticulture, CCS Haryana Agricultural University, Hisar, India
}

\section{A B S T R A C T}

\begin{abstract}
Mushrooms are valuable health food grown commercially in many parts of the India. They are one of the oldest single cell protein foods of man having unique flavour and texture. Mushrooms are good source of fibre and rich in unsaturated fatty acid. In the present study two types of mushrooms namely Agaricus bisporus and Pleurotus sajor caju mushrooms were analyzed to determine their fatty acid composition and dietary fibre constituents. The mushrooms were found to be rich in polyunsaturated fatty acids ( $>75 \%)$, linoleic acid being the most predominant one in both the mushrooms. Among saturated fatty acids, palmitic acid was the major fatty acid. No significant differences were found in saturated and unsaturated fatty acid contents of the two mushrooms. Both Agaricus bisporus and Pleurotus sajor caju mushrooms had good amount of neutral detergent fibre, acid detergent fibre and hemicellulose. Dietary fibre content of Agaricus bisporus and Pleurotus sajor caju mushrooms were 40.52 and 43.73 per cent, respectively.
\end{abstract}

Keywords: Mushroom; Agaricus bisporus; Pleurotus sajor caju; Fatty acids; Dietary fibre

\section{INTRODUCTION}

Mushrooms are popular food items, available commercially in India. Earlier studies (Gruen and Wang, 1982, Zakhary et al., 1993) indicate that mushrooms are highly nutritious and compare favorably with meat, egg and milk. In the terms of amount of crude protein, mushrooms are ranked well above cereals/vegetables or fruits and animal products but below most meats (Chang and miles, 1989). The nutritional values of mushrooms have already been reevaluated on the basis of their low fat, low calories and high mineral content, (Lee et al., 2011). The mushrooms are basically low calorie food. Early people believed mushrooms to be wild food but now it has become very popular and valuable food item in the modern dietary regimes because of its nutritional value.

Dietary fat is a major constituent of the normal diet and necessary to ensure balanced lipid homeostasis. Generally, lipid content of mushroom species is low, however they are very good source of unsaturated fatty acids, which are considered beneficial for health. It is reported that, in fresh mushrooms belonging to different species, the lipid proportion per $100 \mathrm{~g}$ is $1.75-15.5 \%$ in dried mushroom since fresh ones contain high amounts of water (Hong et al., 1988). Many researchers have studied the fatty acid composition of several mushrooms and elucidated their nutritional roles in the human diet (Wang et al., 2001). Barros et al., (2007) reported that the major fatty acids of Agaricus arvensis, Lactarius deliciosus, Lencopaxillus giganteus, Sarcodon imbricatus, and Tricholoma portentosum were linoleic acid and oleic acid.

Besides, they have appreciable amount of fibre also. Compared to other conventional sources of dietary fiber (DF), such as cereals, fruits, legumes and vegetables, mushrooms or fungi are underutilized (Elleuch et al., 2010; Shea et al., 2012). In fact, edible mushrooms or macrofungi are a rich source of some novel DFs that have various beneficial health effects. The mushroom cell wall components are non-digestible carbohydrates (NDCs) that are resistant to human enzymes and can be considered as source of DF. It has been demonstrated by extensive research in the past three decades that sufficient DF intake has benefits for health maintenance and disease prevention including cardiovascular disease, diabetes, cancer and weight

\footnotetext{
*Corresponding author:

Rajni Goyal, University College, Kurukshetra University, Kurukshetra-136119 India. E-mail: shubhi_rgoyal@yahoo.co.in, Mobile: 919416535035
} 
regulation (Theuwissen and Mensink,2008; Charles,2005; Bordonaro and Sartorelli,2008 and Howarth,2001).

Earlier studies (Bobek et al., 1997; Chocksaisawasdee et al., 2010; Yang et al., 2001) have reported consumption of mushroom not only for nutritional attributes, but also for medicinal purposes Mushrooms have been found effective against cancer, cholesterol reduction, stress, insomnia, asthma, allergies and diabetes (Bahl, 1983). Additionally, mushrooms have been known to have an effect on preventing several diseases such as cancer, hypercholesterolemia, and hypertension (Bobek et al., 1998).

In the present study two species namely Agaricus bisporus (white button mushroom) and Pleurotus sajor caju (dhingri mushroom) were analyzed for the fatty acid composition and dietary fibre constituents.

\section{MATERIAL AND METHODS}

\section{Procurement of material}

Fresh white button (Agaricus bisporus) and dhingri (Pleurotus sajor caju) mushrooms were procured from the Department of Plant Pathology, CCS Haryana Agricultural University, Hisar (INDIA). The samples were manually cleaned of dust and other foreign material, dried in oven at $60+2^{\circ} \mathrm{C}$ for $12 \mathrm{hrs}$. and made into fine powder in cyclotec mill $(0.5 \mathrm{~mm}$ sieve) and used for further analysis.

\section{Chemical analysis}

For estimation of fatty acid composition the extracted fat was methylated according to the standard method (Luddy et al., 1968). The analysis of methyl esters were performed with a Nucon 5765 liquid chromatograph equipped with flame ionization detector using a 10'x 1/8" stainless steel column packed with $20 \%$ diethyl glycol succinate (DEGS) on 60-80 mesh chromosorb-W. The column temp. was $190^{\circ} \mathrm{C}$ and flow of nitrogen carrier gas was $35 \mathrm{ml} / \mathrm{min}$. The peaks were identified by comparison of their retention times with those of standard fatty acids. The area under individual peak was calculated by the formula, half the base $\mathrm{x}$ height and converted directly into relative per cent age of individual fatty acids.

Dietary fibre constituents namely, acid detergent fibre $(\mathrm{ADF})$, neutral detergent fibre (NDF), cellulose and lignin were estimated by the method given by Van Soest \& Wines (1967) modified by Arora (1981). Hemicellulose was estimated as the difference between NDF and ADF contents.

\section{Statistical analysis}

The data were subjected to statistical analysis for calculation of mean and standard error. The data were analyzed in complete randomized design for analysis of variance. The data presented are the averages of the results of three replicates with a standard error of less than 5\%(Panse \& Sukhatme, 1961).

\section{RESULTS AND DISCUSSION}

\section{Fatty acid composition of mushrooms}

In the present study, fatty acid composition of two species of mushroom namely Agaricus bisporus and Pleurotus sajor caju mushrooms were analyzed. The results for fatty acid composition, total saturatedfatty acids (SFA) and polyunsaturated fatty acids (PUFA) of the studied mushrooms are shown in Table 1 . The major fatty acids found in the studied samples were linoleic acid (C182 n 6) and oleic acid (C181 n 9), followed by palmitic acid (C16:0). Results reveal that levels of unsaturated fatty acid were higher than saturated ones in both the mushrooms. This result is in agreement with the earlier findings that unsaturated fatty acid content was predominating fatty acid in different species of mushrooms as compared to saturated ones (Senatore, et al., 1988).

Linoleic acid was the major fatty acid detected in all species and it is one of the essential fatty acid which is not synthesized by man. Presence of linoleic acid is quite essential for the normal growth of human beings. It is known that linoleic acid is the precursor of 1-octen-3-ol, known as the alcohol of fungi, which is the principal aromatic compound in most fungi and might contribute to mushroom flavour (Magga, 1981). In addition to linoleic acid, oleic, linolenic, palmitic, behanic, myristic, palmitic and stearic acids were the other fatty acids present in the mushrooms examined. Similar observations have been observed in other mushrooms (Barros, et al., 2007; Lee, et al., 2011).

In earlier studies, Cruz et al., (1997) studied the fatty acid concentration of two different strains of Agaricus

Table 1: Fatty acid composition of Agaricus bisporus and Pleurotus sajor caju mushrooms (\%)

\begin{tabular}{lccc}
\hline Fatty acid & $\begin{array}{c}\text { Agaricus } \\
\text { bisporus }\end{array}$ & $\begin{array}{c}\text { Pleurotus } \\
\text { sajor caju }\end{array}$ & $\mathbf{t}$ calculated \\
\hline Myristic acid (C14:0) & 1.25 & 1.02 & $4.28^{*}$ \\
Palmitic acid (C16:0) & 12.27 & 13.50 & $\mathrm{NS}$ \\
Stearic acid (C13:0) & 4.58 & 2.92 & $6.67^{\star}$ \\
Behanic acid (22:0) & 1.47 & 5.48 & $6.16^{*}$ \\
Total saturated fatty acid & 19.59 & 22.92 & $\mathrm{NS}$ \\
Oleic acid (C18:1) & 8.69 & 9.46 & $\mathrm{NS}$ \\
Linoleic acid (C18:2) & 70.36 & 65.67 & $\mathrm{NS}$ \\
Linolenic acid (C18:3) & 1.36 & 1.95 & $14.60^{*}$ \\
Total unsaturated fatty acid & 80.41 & 77.08 & $\mathrm{NS}$ \\
\hline
\end{tabular}

Values are mean+SD of three replicates. *Statistical significant, NS: Non-significant 
bisporus at different stages of development reported that linoleic acid was major fatty acid whatever the strain or development stage. Longvah \& Deosthale(1998) reported that unsaturated fatty acids were higher than saturated ones in mushrooms viz., Schizophyllum commune and Lentinus edodes. Rai et al., (1988) reported that mushrooms contained 70 percent polyunsaturated fatty acids linoleic acid. USDA Nutrient Data base (1999) reported $0.046 \mathrm{~g}$ saturated fatty acids and $0.006 \mathrm{~g}$ monounsaturated $0.139 \mathrm{~g}$ polyunsaturated fatty acids on fresh weight basis in Agaricus bisporus. The results indicated that mushrooms were rich in polyunsaturated fatty acids, especially linoleic acid and therefore should be included in the diet.

\section{Dietary fiber constitutes of mushrooms}

Mushrooms are good source of fibre. The chemical analysis results for dietary fibre constituent's viz. acid detergent fibre (ADF), neutral detergent fibre (NDF), hemicellulose, cellulose and lignin contents of Agaricus bisporus and Pleurotus sajor caju mushrooms have been shown in Table 2.

Data in Table 2 shows that neutral detergent fibre content was 41.17 and 43.52 per cent in Agaricus bisporus and Pleurotus sajor caju mushrooms. The amount of cellulose and lignin were 10.17 and 7.22 per cent, respectively in Pleurotus sajor caju mushroom and 8.71 and 6.34 per cent, respectively in Agaricus bisporus mushroom. Total dietary fibre, as determined from sum of hemicellulose, cellulose and lignin was 43.73 per cent in Pleurotus sajor caju and 40.52 per cent in Agaricus bisporus mushrooms. Mushrooms are a potential source of dietary fibres due to the presence of non-starch polysaccharides. Total dietary fibre (TDF) in mushrooms is the sum of intrinsic non-digestible carbohydrates, mainly chitin (Vetter 2007).

Total dietary fibre was significantly higher in Pleurotus sajor caju mushroom. Kurasawa et al., (1982) reported less NDF values $(26.3 \%)$, which might be due to modification in the Van Soest (1965) method by incorporating an enzymatic step for amylolysis ( $\alpha$-amylose pretreatment), whereas ADF value was reported to be 13.3 per cent. Ragunathan and co-workers, (1996) reported 28.4 to 44.8 per cent cellulose, 28.5 to 41.2 per cent hemicellulose and 13.0 to

Table 2: Dietary fibre constituents of Agaricus bisporus and Pleurotus sajor caju mushrooms (g/100g on dry weight basis)

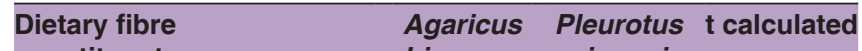
constituents bisporus sajor caju

\begin{tabular}{llll}
\hline Neutral detergent fibre (NDF) & $41.17 \pm 0.55$ & $43.52 \pm 0.72$ & $17.27^{*}$
\end{tabular}

Acid detergent fibre (ADF) $\quad 15.72 \pm 0.19 \quad 17.20 \pm 0.01 \quad 7.27^{*}$

Hemicellulose $\quad 25.47 \pm 0.5226 .32 \pm 0.77 \quad 3.23^{*}$

$\begin{array}{llll}\text { Cellulose } & 8.71 \pm 0.04 & 10.17 \pm 0.08 & 15.61^{*}\end{array}$

Lignin $\quad 6.34 \pm 0.05 \quad 7.22 \pm 0.02 \quad 15.08^{*}$

Total Dietary Fibre (TDF) $\quad 40.52 \pm 0.53 \quad 43.73 \pm 0.83 \quad 3.261^{*}$

Values are mean+SD of three replicates. ${ }^{*}$ Statistical significant
17.0 per cent lignin in the fruit bodies of Pleurotus sajor caju. Cheung (1997) determined the total dietary fiber by AOAC and the Upssala method and reported that NDF value of Agaricus bisporus was still much higher than the total dietary fiber values from both the methods. This could possibly be due to the inadequate removal of glycogen \& protein. Manzi et al., (2001, 2004) reported dietary fibre values in fresh fruit bodies of P. ostreatus (47.3\% TDF) and P. eryngii $(34.6 \% \mathrm{TDF})$.

\section{CONCLUSION}

Thus it can be inferred that both varieties of mushrooms were rich in unsaturated fatty acid i.e. linoleic and oleic acid and had appreciable amount of palmitic acid. The high amount of unsaturated fatty acid present in both mushrooms is comparable to that of present in safflower oil which is considered to be most suitable for prevention of heart diseases (Hughes, 1972). The total dietary fibre content was high in both the mushrooms and should be regarded as high fibre food.

\section{ACKNOWLEDGEMENTS}

Council of Scientific and Industrial Research, New Delhi (India) in the form of Senior Research Fellow supported the project. This is gratefully acknowledged.

\section{Author contribution}

All authors contributed equally in this work.

\section{REFERENCES}

Arora, S. K. 1981. Analytical techniques for quality evaluation. Forage Res. 7A: 197-213.

Bahl, N. 1983. Medicinal values of edible fungi. In Indian Mushroom Science II. Proceedings of the International Conference on Science and Cultivation Technology of edible Fungi at Srinagar 9-11 ${ }^{\text {th }}$ September. Pp 203-209.

Barros, L., P. Baptista., D. M. Correia., S. Casal., B. Oliveira and I. C. F. R. Ferreira. 2007. Fatty acid and sugar compositions, and nutritional value of five wild edible mushrooms from Northeast Portugal. Food Chem. 105(1): 140-145.

Bobek, P., L. Ozdin. and I. Kajabo. 1997. Dose dependent hypocholesterolemic effect of oyster mushroom (Pleurotus ostreatus) in rats. Physiol. Res. 46(4): 327-329.

Bobek, P., L. Ozdín and Š. Galbavý. 1998. Dose-and time-dependent hypocholesterolemic effect of oyster mushroom (Pleurotus ostreatus) in rats. Nutrition. 14(3): 282-286.

Bordonaro, M. and A. C. Sartorelli. 2008. Fiber, cancer stem cells and the Wnt signalling continuum. Chin. J. Cancer. 27: 1-4.

Chang, S. T. and P. G. Miles. 1989. Edible Mushrooms \& Their Cultivation. CRC Press, Boca Raton, p. 345.

Chang, S. T., O. W. Lau and K. V. Cho. 1980. The cultivation and nutritional value of Pleurotus sajor-caju. Eur. J. Appl. Mocrobiol. Biotechnol. 12: 58-62. 
Cheung, P. C. K. 1997. Chemical evaluation of some lesser known edible mushroom mycelia produced in submerged culture from soya milk waste. Food Chem. 60: 61-65.

Charles, S. B. 2005. Dietary fiber, glycemic response, and diabetes. Mol. Nutr. Food Res. 49: 560-570.

Chockchaisawasdee, S., S. Namjaidee, S. Pochana and C. E. Stathopoulos. 2010. Development of fermented oystermushroom sausage. Asian J. Food Agro-Industry. 3: 35-43.

Cruz, C., C. Noel-Suberville and M. Montury. 1997. Fatty acid content and some flavour compound release in two strains of Agaricus bisporus according to three stages of development. J. Agric. Food Chem. 45(1): 64-67.

Elleuch, M., D. Bedigian, O. Roiseux, S. Besbes, C. Blecker and H. Attia. 2010. Dietary fiber and fiber-rich by-products of food processing: characterization, technological functionality and commercial application: A review. Food Chem. 124: 411-421.

Gruen, E. H. and M. W. Wang. 1982. Distribution of cellular amino acids, protein and total organic nitrogen during fruit body development in Flammulina veluptipes. Can. J. Biol. 60(8): 1330-1341.

Hong, J. S., Y. H. Kim., K. R. Lee., M. K. Kim., C. I. Cho and K. K. H. Part. 1988. Composition of organic abd fatty acid in Pleurotus ostreatus, Lentinus edodes and Agaricus bisporus. Korean J. Food Sci. Technol. 20: 100-105.

Howarth, N. C., E. Saltzman and S. B. Roberts. 2001. Dietary fiber and weight control. Nutr. Rev. 59: 129-139.

Huges, D. H. 1972. Preliminary characterization of the lipid constituents of the cultivated mushroom Agaricus campestris. Mushroom Sci. 5: 540-545.

Kurasawa, S. I., T. Sugahara and J. Hayasha. 1982. Studies on dietary fibre of mushrooms and edible wild plants. Nutr Rep. Int. 26: 167-173.

Lee, K. J., I. J. Yun., K. H. Kim., S. H. Lim., H. J. Ham., W. S. Eum and J. H. Job. 2011. Amino acid and fatty acid compositions of Agrocybe chaxingu, an edible mushroom. J. Food Compost. Anal. 24(2): 175-178.

Li, C., Z. Li, M. Fan., W. Cheng., Y. Long., T. Ding and L. Ming. 2006. The composition of Hirsutella sinensis, anamorph of Cordyceps sinensis. J. Food Compost. Anal. 19(8): 800-805.

Longvah, J. and Y. G. Deosthale. 1998. Compositional and nutritional studies on edible wild mushroom from Northeast India. Food Chem. 63(3): 331-334.

Luddy, F. E., R. A. Bardford and P. M. Heind.1968. A rapid quantitative for the preparation of methyl esters fat and other fat. J. Am. Oil Chem. 42: 549-552.

Maga, J. A. 1981. Mushroom flavor. J. Agric. Food Chem. 29: 1-4.

Manzi, P., A. Aguzzi and L. Pizzoferrato. 2001. Nutritional value of mushrooms widely consumed in Italy. Food Chem. 73: 321-325.

Manzi, P., S. Marconi., A. Aguzzi and L. Pizzoferrato. 2004. Commercial mushrooms: Nutritional quality and effect of cooking. Food Chem. 84: 201-206.

Panse, V. G. and P. V. Sukhatme. 1961. Statistical Methods of Agricultural Coworkers. $2^{\text {nd }}$ ed. Indian Council of Agricultural Research, New Delhi, Pp. 12-87.

Ragunathan, R., R. Gurusamy., M. Palaniswamy and K. Swaminathan. 1996. Cultivation of Pleurotus spp. On various agro-residues. Food Chem. 55(2): 139-144.

Rai, R. D., O. P. Ahlawat and R. N. Verma. 1998. Nutritional value and postharvest technology of mushrooms. In: Proceedings of the Short Course on "Recent Sdvances in the Cultivation Technology of Edible Mushrooms". July 29 to Auguest.7, at National Research Centre for Mushroom, Chambaghat, Solan.

Senatore, F., A. Dini and A. Marino.1988. Chemical constituents of some Basidiomycetes. J. Sci. Food Agric. 45: 337-345.

Shea, N., O'. E. K. Arendt and E. Gallagher. 2012. Dietary fibre and phytochemical characteristics of fruit and vegetable by-products and their recent applications as novel ingredients in food products. Innovative Food Sci. Emerg. Technol. 16: 1-10.

Singh, S., G. K. Kumar and S. Singh. 1995. Production processing and consumption patterns of mushrooms. Indian Food. Ind. 14(6): 38-47.

Theuwissen, E. and R. P. Mensink. 2008. Water-soluble dietary fibers and cardiovascular disease: A review. Physiol. Behav. 94: 285-292.

USDA. Nutrient Database for Standard Reference. Release 13, (November 1999).

Van Soest, P. J. 1965. Use of detergents in analysis of fibrous feeds II. Study of effects of heating and drying on yield of fibre and lignin in forages. J. AOAC. 48: 785-789.

Van Soest, P. J. and R. H. Wine. 1967. Use of detergents in the analysis of fibrous foods: Determination of plant cell wall constituents. J. Assoc. Off. Anal. Chem. 50: 50-55.

Wang, D., A. Sakoda and M. Suzuki. 2001. Biological efficiency and nutritional value of Pleurotus ostreatus cultivated on spent beer grain. Bioresour. Technol. 78(3): 293-300.

Yang, J. H., H. C. Lin and J. L. Mau. 2001. Non-volatile taste components of several commercial mushrooms. Food Chem. 72: $465-471$.

Vetter, J. 2007. Chitin content of cultivated mushrooms Agaricus bisporus, Pleurotus ostreatus and Lentinula edodes. Food Chem. 102: 6-9.

Zakhary, W. J., R. A. Abu-Bakr, M. T., ElMhoy and M. A. El-Tbey. 1983. Chemical composition of world mushrooms collected from Alexandria., Egypyt. Food Chem. 11(1): 31-41. 